Gi rask respons på artikler gjennom artikkelens kommentarfelt på tidsskriftet.no. Respons som er postet innen én måned etter at artikkelen er publisert, vurderes for publisering som Brev til redaktøren i papirutgaven.

Redaksjonen forbeholder seg retten til å foreta redaksjonelle endringer.

Forfattere av vitenskapelige artikler har tilsvarsrett, jf. Vancouver-gruppens regler.

\section{Om forførende ordbruk}

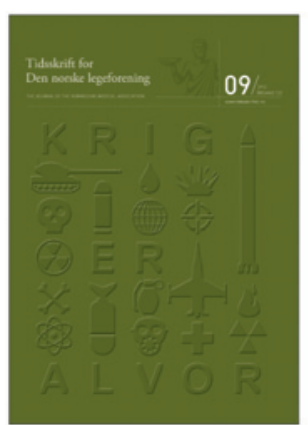

«Det er klart at Erlend Hem peker på en verdibasert utfordring, for å si det sånn, når han i Tidsskriftet nr. 9/2012 anbefaler å styre unna moteordene (1), hadde jeg nær sagt.»

En slik setning ville Harry Frankfurt (2) kalle «bullshit», og støtte seg på Max Black (3), som mente moderne språkbruk var full av «humbug». Begge er enige om at de to ordene står for det samme, men at det siste er mer dannet.

Black definerer humbug som forførende tilsløring - grensende til usannhet - særlig om egne eller andres tanker, følelser, gjerninger eller holdninger. På norsk står ordet for bløff og svindel. For å dekke hele skalaen av det Hem advarer mot, har vi også andre og mer folkelige utsagn: ordsvada, munnsvada, ordgyteri, tullprat, forløyenheter, munnhell. Listen tyder på at fenomenet svulstig og innholdsløst ordbruk heller ikke er ukjent på folkemunne. Vi har også et ordspråk som sier at det dunkelt sagde er det dunkelt tenkte. Man kan vel ofte i offentlige ordskifter få det inntrykk at det gjelder å erobre taletid uansett hva man måtte ha på hjertet. Med ord skal ord fordrives, det gjelder å stoppe munnen på motparten med varierte gjentakelser av tvilsomt innhold.

Det nye ved saken er vel at munnsvadaen i vår tid har fått så stor utbredelse også i offentlig og såkalt seriøst ordskifte. Mas(s)emediene må vel ta ansvar for det. Det er her ordbruken formes av de kjendiser og autoriteter som slipper til.

Min språkfilosofiske guru Wittgenstein ser mer alvorlig på ordenes funksjoner. Han mener ord skaper virkelighet, særlig vedrørende ideologiske og verdiladede forhold. Han hevder at innsikter på slike områder bare kan erverves og forbedres gjennom avklarende skepsis til de språkbilder forståelsen knytter seg til. Ord og begreper er under forvandlingens lover, ofte uten at vi reflekterer over det. Ikke minst medisinen med sitt nye ekspansive operasjonsområde burde bli mer kritisk til den ordbruk den blir utsatt for. Det er for eksempel nå ingen grense for de mange ubehag som får sykdomsstempel. Dette bidrar igjen til at ordet årsak blir misbrukt til forklaring på alle mulige forhold som skyldes grunner som svever i det blå. Det som før var lidelser og avvik, blir umerkelig til sykdom hvis årsak ligger i en diagnose. Slik endret språkbruk reiser spørsmål som ikke stilles fordi det kan gi svar tiden ikke lenger vil godta. Ikke minst drar nytt innhold i gamle begreper medisinsk praksis inn på virksomhetsområder den ikke har styring med. Velferdssamfunnet krever stadig flere sykdomsbekreftende attestasjoner for ditt og datt som har lite med sykdom i gammeldags forstand å gjøre, og i retten strides det for tiden om terroristens ugjerninger er forårsaket av psykiatriske diagnoser, politisk villfarelse eller skyldes pur ondskap.

Vi opplever mye språklig forvirring i våre dager, mer enn før, da ordenes betydning var i synlig praksis. Nå svever mange ord rundt i begrepsjungelens lufttomme rom, til størst glede for dem som har ordene i sin makt. Språkets veier er uransakelige.

Per Sundby

hilchensenior@gmail.com
Per Sundby (f.1926) er professor emeritus i sosialmedisin, Universitetet i Oslo

Ingen oppgitte interessekonflikter.

\section{Litteratur}

1. Hem E Styr unna moteordene Tidsskr Nor Legeforen 2012: 132: 1128-9.

2. Frankfurt HG. On bullshit. Princeton, NJ: Princeton University Press, 2005

3. Black M. The prevalence of humbug. Ithaca, NY: Cornell University Press, 1985.

\section{Allergi mot moteord}

Artikkelen om moteordene i Tidsskriftet nr. 9/2012 er det beste jeg har lest på lenge! Endelig fant jeg en godt begrunnet liste med «verstingene» i det norske språket. Mine tre «topp på bånn» er: fokus, i forhold til og ståsted. Jeg får nærmest en allergisk reaksjon når jeg hører eller leser dem. Jeg skal videreformidle denne strålende artikkelen til mine kolleger! Forslag til flere ord på listen: implementere, enn så lenge, ta på alvor...

\section{Thurid Vold}

thurid.vold@hioa.no

Thurid Vold er høgskolelektor i kunsthistorie ved Institutt for estetiske fag, Høgskolen i Oslo og Akershus. Ingen oppgitte interessekonflikter.

Litteratur

1. Hem E. Styr unna moteordene. Tidsskr Nor Legeforen 2012; 132: 1128-9.

\section{En krevende utfordring}

Takk for artikkelen om moteord i Språkspalten i Tidsskriftet nr. 9/2012 (1). Selv satt jeg og koste meg med ordlisten, helt til jeg skuffet måtte innse at det ultimate (det ordet manglet forresten) moteordet manglet. For å si det som en politiker ville ordlagt seg, det var en krevende utfordring for meg å innse at ordet krevende var utelatt! Jeg vil nærmest kreve at det tas inn! Hvorfor er ingen ting vanskelig lenger? Og så savnet jeg beslutningsstøtte (kjenner jeg blir litt kvalm nå, så jeg stopper der).

For øvrig - kom gjerne med mer språkrøkt!

\section{Ole Magnus Filseth}

ole.magnus.filseth@unn.no

Ole Magnus Filseth (f. 1961) er overlege ved Akuttmedisinsk klinikk, Universitetssykehuset Nord-Norge, Troms $\varnothing$. 